\title{
When Voters Choose the Sentence: The Drug Policy Initiatives in Arizona, California, Ohio, and Michigan
}

Michael M. O'Hear

Marquette UniversityLaw School, michael.ohear@marquette.edu

Follow this and additional works at: http://scholarship.law.marquette.edu/facpub

Part of the Law Commons

Publication Information

Published as Michael M. O’Hear, When Voters Choose the Sentence: The Drug Policy Initiatives in Arizona, California, Ohio, and Michigan, 14 Fed. Sent'g Rep. 337 (2002). (c) 2002 by the Regents of the University of California on behalf of the Vera Institute of Justice. Copying and permissions notice: Authorization to copy this content beyond fair use (as specified in Sections 107 and 108 of the U. S. Copyright Law) for internal or personal use, or the internal or personal use of specific clients, is granted by the Regents of the University of California on behalf of the Vera Institute of Justice for libraries and other users, provided that they are registered with and pay the specified fee via Rightslink ${ }^{\circledast}$ on Caliber (http://caliber.ucpress.net/) or directly with the Copyright Clearance Center, http://www.copyright.com.

\section{Repository Citation}

O'Hear, Michael M., "When Voters Choose the Sentence: The Drug Policy Initiatives in Arizona, California, Ohio, and Michigan" (2002). Faculty Publications. Paper 114.

http://scholarship.law.marquette.edu/facpub/114

This Article is brought to you for free and open access by the Faculty Scholarship at Marquette Law Scholarly Commons. It has been accepted for inclusion in Faculty Publications by an authorized administrator of Marquette Law Scholarly Commons. For more information, please contact megan.obrien@marquette.edu. 


\section{When Voters Choose the Sentence: The Drug Policy Initiatives in Arizona, California, Ohio, and Michigan}

Direct democracy has played an increasingly important role in state sentencing policy over the past decade. In the I990's, voters in several states adopted three-strikes and two-strikes laws, which impose strict mandatory minimum sentences on repeat offenders. More recently, voters have adopted initiatives that require treatment in lieu of incarceration for some drug possession defendants. Arizona initiated the trend by adopting Proposition 200 in I996. California followed suit with its Proposition 36 in 2000 . Ohio and Michigan will have similar initiatives on the ballot in 2002 .

Should the voters make sentencing policy through direct democracy? In their critical account of California's three-strikes initiative, Professors Franklin E. Zimring, Gordon Hawkins, and Sam Kamin suggest that the processes of direct democracy are ill-suited for making sentencing policy. In particular, they suggest there is a tendency towards excessive harshness when voters sentence by ballot initiative. They identify several reasons to expect undue harshness, including: (I) "the reduction of [policy] choice to a single special-interestauthored yes-or-no vote"; (2) the use of mandatory general standards, which tends to focus policymaking on worst-case scenarios and "invites emphasis on symbolic aspects of condemnation and punishment"; and (3) a tendency for voters, faced with an abstract choice between more and less severe punishment, to favor the former "simply as a way of expressing hostility towards those who commit crime." 4

In a sense, the drug initiatives offer an intriguing counterpoint to the excessive harshness hypothesis. After all, these initiatives, in contrast to the three-strikes initiatives, are designed to reduce sentence lengths. The drug initiatives demonstrate that a well-funded interest group may actually push for less severe penal laws, and suggest that the power of such an interest group to shape the terms of public debate may overcome any natural tendencies by the electorate towards greater severity. Yet, as I will suggest in this Article, the analysis by Zimring and his colleagues nonetheless holds much currency in connection with the drug initiatives.

In order to provide a context for this analysis, Part I

offers additional background on the drug initiatives and provides a comparison of their substantive provisions. Part II discusses assessments of the effectiveness of the Arizona and California initiatives. Part III offers a critique of the initiatives, drawing on the prior work of
Zimring, Hawkins, and Kamin. In particular, I am concerned by the unjustified disparities in the initiatives' treatment of eligible and ineligible defendants.

\section{Content of the Drug Initiatives}

The state drug initiatives have been supported by a national organization now known as the Campaign for New Drug Policies. The efforts of this organization, in turn, have been funded by three wealthy businessmen (investor George Soros, University of Phoenix founder John Sperling, and insurance executive Peter Lewis), whose contributions have permitted advocates to mount multimillion-dollar promotional campaigns. Additional initiatives seem likely in the future, with a Florida campaign already slated for 2004 .

While the different state initiatives may be viewed as manifestations of a broader national effort to reform drug laws, the initiatives differ markedly in their structure and technical details. Accordingly, this Part compares and contrasts the Arizona, California, Ohio, and Michigan Initiatives.

\section{A. Proposition 200}

Arizonans enacted Proposition 200 with $65 \%$ of the vote in 1996 . In its core sentencing provision, Proposition 200 requires that "any person who is convicted of the personal possession or use of a controlled substance" be placed on probation (in lieu of incarceration) and required to undergo drug treatment under court supervision. ${ }^{5}$ Proposition 200 excludes several categories of defendant from this preferential treatment, including: (I) any defendant with a violent criminal history; (2) any defendant convicted of possession for "sale, production, manufacturing, or transportation for sale"; and (3) any defendant with two prior convictions for personal possession or use. ${ }^{6}$

In addition to these provisions, Proposition 200 also modified drug policy in a variety of other ways. Perhaps most notably, the Proposition decriminalized the medical use of controlled substances by a terminally or seriously ill patient pursuant to a doctor's prescription.? Additionally, while easing penalties for nonviolent drug offenders, the Proposition stiffened sanctions against those convicted of committing a violent crime while under the influence of a controlled substance; offenders in this category were precluded from parole eligibility. ${ }^{8}$ Finally, Proposition 200 allocated certain tax revenues

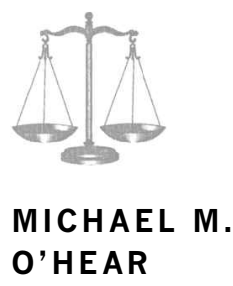

Assistant Professor, Marquette University Law School 
to a Drug Treatment and Education Fund. Half of the money in this fund is committed to paying for drug treatment. 9

\section{B. Proposition 36}

California's Proposition 36 was enacted in 2000 with $61 \%$ of the vote. Like Proposition 200, Proposition 36 mandates probation and treatment in lieu of incarceration for eligible drug offenders. ${ }^{\text {}}{ }^{\circ}$ Also like its Arizona counterpart, Proposition 36 targets possession for personal use, and excludes defendants convicted of possession for sale, production, or manufacturing. II Additional exclusions are similar in spirit to Arizona's, but rather different in the details. For instance, the law excludes defendants with prior violent felonies, but provides an exception if the defendant has remained out of prison and avoided felony or violence convictions for a period of five years. ${ }^{12}$ Also excluded are certain defendants who: (I) are convicted of a non-drug offense in the same proceeding as the drug offense; (2) use a firearm while possessing or being under the influence of specified hard drugs; or (3) refuse treatment. ${ }^{\text {i3 }}$ If the court finds the defendant "unamenable" to treatment, the court must, under certain circumstances, impose a 30-day jail term. ${ }^{14}$

Unlike Arizona's Proposition 200, California's Proposition 36 provides for revocation of probation, albeit through a somewhat complicated process. ${ }^{15} \mathrm{~A}$ defendant who commits one drug-related probation violation may have probation revoked (and hence face incarceration) only if the state proves by a preponderance of the evidence that the defendant "poses a danger to the safety of others." ${ }_{16}$ Revocation becomes progressively easier with successive violations. ${ }^{17}$

Proposition 36 contains analogous provisions for parolees, generally prohibiting revocation of parole for the first-time violation of a drug-related condition. ${ }^{18}$ Additional provisions provide specific funding levels for drug treatment through the 2005-06 fiscal year.

\section{Ohio Initiative}

The Ohio Initiative takes the form of a proposed amendment to the state constitution. ${ }^{19}$ If passed, the Initiative will provide treatment in lieu of incarceration, but structured in a somewhat different manner than Propositions 200 and 36 . First, the defendant must affirmatively request treatment. ${ }^{\circ}$ Second, the court must make a determination that the defendant is eligible for treatment. ${ }^{2 x}$ Eligibility criteria generally parallel those in Proposition 36, with a few additional provisions that both constrict and expand eligibility. For instance, a defendant may be excluded if convicted of, or charged with, driving under the influence of drugs or alcohol in the same proceeding as the drug possession charge. ${ }^{22}$ Thus, if police find drugs in the car of an intoxicated motorist, the motorist might face incarcera- tion on a possession charge if simultaneously charged with DUI. ${ }^{23}$

On the other hand, the Ohio Initiative permits the court to order treatment for some defendants who have two or more prior convictions for personal use or possession. Such repeat offenders are eligible if the court determines that treatment is "in the best interests of the offender and the public" and the offender is not otherwise excluded. ${ }^{24}$ Otherwise, repeat offenders are subject to a sentence of incarceration of no more than 90 days. Likewise, a defendant with concurrent charges for a nonviolent offense resulting from drug abuse or addiction may also qualify for treatment if it is "in the best interests of the offender and the public." ${ }_{25}$

Like Proposition 36, and unlike Proposition 200, the Ohio Initiative provides for the removal of a defendant from a treatment program for violations of program requirements. Again like Proposition 36, the removal provisions are complicated, generally focusing on the severity and number of violations, and whether the defendant poses a danger to the safety of others. ${ }^{26}$ Unlike Proposition 36, however, the Ohio Initiative imposes a 9o-day limit on the incarceration of a defendant who is removed from treatment. ${ }^{27}$ A defendant who otherwise fails to complete a treatment program successfully may not be incarcerated..$^{28}$

The Ohio Initiative specifies funding levels for drug treatment through the 2009 fiscal year; thereafter, funding is left to the legislature's discretion, "provided that adequate resources are appropriated to continue the [Initiative's] purposes." ${ }^{29}$ Additionally, the Initiative specifies that the legislature may not cut preexisting funding levels for substance abuse treatment and rehabilitation for at least six years; funding provided under the new law would be in addition to (not in lieu of) prior funding..$^{\circ}$

\section{Michigan Initiative}

Like the Ohio Initiative, the Michigan Initiative would amend the state constitution. ${ }^{3 \mathrm{I}}$ In other respects, however, the Michigan Initiative differs substantially from the other drug initiatives. The proposed constitutional amendment would create a Drug Sentencing Commission, which would be charged with developing guidelines for sentencing in drug cases, as well as revoking probation or parole for drug violations. ${ }^{32}$ The Commission's mandate in devising the guidelines would be broad:

The commission guidelines shall be calculated to: adequately punish violations of law, protect public safety, ensure that prison and jail space are used cost-effectively, preserve judicial discretion while reducing disparities in sentencing, promote the treatment and rehabilitation of substance-abusing offenders, and facilitate the successful reentry of offenders into the community. ${ }^{33}$ 
The Commission itself would be comprised of twentyfive members representing a wide range of different interests, but seemingly tilted towards a treatmentoriented perspective. ${ }^{34}$

While the Michigan Initiative would grant broad authority to the Commission to restructure drug sentencing, treatment would be required in lieu of incarceration for a class of personal possession drug offenders similar to that which is protected by the other drug initiatives. ${ }^{35}$ Some of the details, however, would be left to a committee comprised of certain members of the Commission. For instance, the committee would establish guidelines as to which concurrent offenses would be disqualifying (though some offenses, including DUI, are established by the Initiative itself to be disqualifying); how to handle repeat offenders; and how to handle program violations..$^{36}$ The Initiative also mandates that judges be provided with discretion to offer treatment to some defendants who have a concurrent charge for a nonviolent offense or who have previously completed drug treatment programs under the Initiative. ${ }^{37}$ Also, incarceration may not be ordered for first- or second-time program violations..$^{38}$ Defendants who are removed from treatment may be sentenced to a maximum of 60 days, or six months for a third or subsequent offense. ${ }^{39}$

In order to ensure the effectiveness of the new guidelines, the Initiative abrogates all preexisting mandatory minimum sentences for drug offenses. $4^{\circ}$ However, the Initiative also imposes a new twenty-year mandatory minimum for "major drug traffickers," which is defined in part by reference to the net profits sought or gained in a drug trafficking scheme..$^{4^{\mathrm{I}}}$

Like the Ohio Initiative, the Michigan Initiative requires that current drug treatment funding levels be maintained, and that specified additional sums also be allocated to achieve the purposes of the Initiative for at least a six-year period. ${ }^{2}$

\section{E. Summary}

There are a few notable differences among the initiatives. First, the Ohio and Michigan Initiatives would not merely create new statutory law, but actually amend the state's constitution. Presumably, proponents have chosen this strategy in order to prevent the legislature from modifying or undermining the new law.

Second, only the Michigan Initiative creates a new sentencing commission with broad authority to promulgate guidelines for all manner of drug offenses. The other initiatives focus more narrowly on the nonviolent possession offenses.

Third, the later initiatives provide more extensive and technically precise lists of excluded offenders than Proposition 200. The exclusion provisions focus on violent offenders, recidivists, drug traffickers, and defendants facing concurrent charges for non-drug crimes. Additionally, California excludes offenders who use a firearm while in possession, or under the influence, of certain hard drugs. The Ohio and Michigan Initiatives would exclude offenders who are concurrently charged with, or convicted of, driving under the influence of alcohol or drugs.

Fourth, unlike Proposition 200, the later initiatives provide for offenders to be removed from treatment for violating program requirements. However, the standards for removal are high, and (under the Ohio and Michigan Initiatives) the maximum period of incarceration would be relatively short (ranging from 60 days to six months, depending on the state and the circumstances).

Fifth, under the Ohio and Michigan Initiatives, defendants must apply for treatment in lieu of incarceration. While certain defendants would automatically qualify, the judge would be given discretion to include a few categories of otherwise ineligible applicants.

Sixth, besides carving out a treatment requirement for certain offenders, California's Proposition 36 otherwise leaves preexisting laws largely intact; the other initiatives make more significant ancillary reforms. Arizona's Proposition 200 bars early release of some violent offenders and decriminalizes some medical uses of controlled substances. (Californians had already legalized medical marijuana by the time they voted on Proposition 36.43) The Ohio Initiative would impose a 90-day cap on incarceration for some offenders who do not qualify for, or are removed from, treatment programs. The Michigan Initiative would broadly restructure drug sentencing by repealing all preexisting mandatory minimums, imposing a new mandatory minimum for major drug traffickers, and establishing new drug sentencing guidelines.

Variation among the initiatives may seem odd in light of the fact that they arise from a coordinated national effort to reform drug laws. The differences may be due in part to the different legal and political circumstances in each state. For instance, the Michigan Initiative's assault on mandatory minimums is not surprising in a state that has enacted unusually tough and controversial mandatory minimums for drug offenses. ${ }^{44}$

Differences may also be due in part to knowledge gained from the implementation of earlier initiatives. For instance, after an early court ruling that Proposition 200 did not apply to drug paraphernalia cases, prosecutors began to charge drug possession cases as paraphernalia cases to circumvent the initiative. ${ }^{45}$ Not surprisingly, the later initiatives specify that drug paraphernalia charges are not disqualifying.

\section{Effectiveness}

Supporters of the Ohio and Michigan Initiatives tout the effectiveness of the earlier measures in Arizona and California. Existing data suggests that Proposition 200 has indeed diverted a substantial number of defendants 
from prison into treatment. However, many questions remain as to the overall effectiveness of the new law. With its shorter history, the effectiveness of Proposition 36 is even more uncertain.

\section{A. Proposition 200}

Arizona's Adult Probation Services Division recently conducted a study of money saved under Proposition 200 in fiscal year I999. Based on historical trends, the study determined that the law resulted in a total of 390 diversions from prison..$^{6}$ Taking into account the relative costs of imprisonment and treatment, the study concluded that the state saved approximately $\$ 6.7$ million as a result of the diversions. 47

While a good starting point, the study's assessment of costs and benefits remains, by its own admission, incomplete..$^{8}$ It is unclear, for instance, whether the new system will succeed in rehabilitating offenders any more effectively than the old. Without the threat of incarceration hanging over their heads, it is possible the defendants will not take treatment programs seriously. Indeed, in I999, 36\% of the defendants covered by the mandatory treatment law failed to comply with program requirements. 49 If Proposition 200 fails to deliver significant rehabilitation benefits-at the same time that it is diminishing the incapacitation benefits of the old system ${ }^{50}$ - it is possible that the new law will actually impose increased net costs on society.

\section{B. Proposition 36}

Proposition 36 became effective on July I, 200 I. Available data indicates that several thousand defendants were referred for treatment during the first year the law was in effect, and that the state's treatment capacity grew substantially. ${ }^{51}$ At present, however, it is unclear to what extent the treatment referrals represent true diversions from prison. Moreover, questions have been raised as to the adequacy of funding and treatment options in some counties. ${ }^{22} \mathrm{~A}$ thorough assessment of these and other concerns may have to wait, however, until the University of California at Los Angeles completes a projected five-year study of the new law.

\section{Areas of Concern}

\section{A. Handling of Eligible Defendants}

Many critics of the drug initiatives have focused their attacks on the way that treatment is structured for eligible defendants. In particular, critics maintain that a successful drug treatment program requires both carrots and sticks. ${ }^{53}$ Because the initiatives prohibit, or severely curtail, incarceration for eligible defendants, such defendants may lack sufficient incentives to participate meaningfully in treatment. Thus, critics often complain that the initiatives merely provide for "revolving-door" treatment. ${ }^{54}$ They prefer the drug court model, in which judges can freely employ graduated sanctions, including incarceration, in order to enforce compliance with treatment programs. ${ }^{55}$

Proponents respond that drug courts are underfunded, reach only a small percentage of drug offenders, and are subject to legislative budget cuts. The initiatives are touted as a way to make "every courtroom in [the state] capable of being a drug court." ${ }^{66}$ Proponents also question whether the threat of incarceration actually makes a treatment program more effective. ${ }^{57}$ Ultimately, though, the initiatives' departure from a true carrots-and-sticks drug court model seems difficult to justify without regard to skepticism of judicial power..$^{8}$ After all, if their supporters really wanted to transform every court into a drug court, the initiatives could simply mandate as much. Instead, the initiatives strip from judges the ability to incarcerate eligible defendants. Proponents apparently doubt that judges would exercise their discretion to incarcerate in an appropriate manner. 59

Indeed, the drug initiatives seem to reflect the same "politics of mistrust" that Zimring, Hawkins, and Kamin identified in their study of the California threestrikes law, which they characterized as "one step in a campaign to take decision making out of the hands of as many government officials as possible." ${ }^{\circ 0}$ Here the targets of mistrust are state legislatures, who threaten funding for drug courts and treatment programs, and state judges, who do not appropriately use their powers to incarcerate drug offenders. (To be sure, the Ohio and Michigan Initiatives appear somewhat less "mistrustful" than their predecessors, inasmuch as they provide for some judicial discretion to determine eligibility, some judicial power to remove program participants, and (in Michigan) the creation of a significant new governmental entity (the drug sentencing commission).)

Is mistrust justified? Thorough analysis of this question lies beyond the scope of this Article, but a few preliminary observations will be attempted. Consider first the legislature. Can the legislature be trusted to provide appropriate levels of support for treatmentoriented responses to possession offenses? The case for mistrust might look something like this: As William J. Stuntz recently argued, legislators have powerful institutional incentives to facilitate the successful prosecution of crimes. ${ }^{61}$ Harsh statutory sentences advance this institutional interest by providing prosecutors with greater leverage in plea-bargaining. ${ }^{62}$ The institutional interest is also advanced by creating (or retaining) easy-to-prove, lesser-included offenses, such as possession. ${ }^{63}$ From this point of view, the legislature might indeed be disinclined to provide non-punitive sentencing alternatives for possession defendants.

This theory seems undermined, however, by reality: as discussed elsewhere in this issue, several state legislatures have recently scaled back penalties for possession offenses. ${ }^{64}$ However, these legislative policy 
changes are arguably a function of short-term budget pressures, and not an indication of a long-term commitment to treatment. Additionally, initiative proponents might argue that legislatures have only begun to scale back penalties because the decisive victories of Propositions 200 and 36 demonstrated that treatment has substantial support among voters. In short, recent developments may simply be the exception that proves the rule.

How about judges: Can they be trusted to utilize incarceration appropriately when dealing with drug offenders? Conventional drug courts have a track record of at least modest success in reducing drug use and other criminal behavior by program participants..$^{65}$ Initiative proponents contend, however, that comparable success could be achieved without incarceration. The evidence from Arizona suggests that Proposition 200 has resulted in lower rates of incarceration for lowlevel drug offenses, but the consequences for public safety and long-term rehabilitation remain unclear. Until these issues are better understood, we will have difficulty in saying with confidence when incarceration is justifiable, and, accordingly, whether judges utilize incarceration appropriately.

In light of the uncertainties, proponents may have made an unfortunate decision in framing the Ohio and Michigan Initiatives as constitutional amendments. While some skepticism of the legislature is perhaps appropriate, recent sentencing reforms in such states as Connecticut and Louisiana suggest that legislators may indeed prove responsive to demands for treatmentoriented policies once their political salience is demonstrated. To the extent that the Ohio and Michigan Initiatives make new law that the legislature cannot readily modify, they may represent too inflexible a commitment to policies whose effectiveness has yet to be fully demonstrated.

\section{B. Handling of Ineligible Defendants}

Under Propositions 200 and 36, ineligible defendants are sentenced as they would have been in the absence of the new law. Under the Ohio and Michigan Initiatives, ineligible defendants generally fall into one of two categories. If ineligible due to multiple prior possession offenses, then the defendant would face the possibility of incarceration, with maximum sentences ranging from 60 days to six months. If ineligible for other reasons, then the defendant would be sentenced as under the preexisting law (in Ohio) or under new drug sentencing guidelines (in Michigan). Thus, putting aside Michigan, ineligible defendants are generally subject to the entire body of old sentencing laws, including, in some cases, mandatory minimums and high maximums. By contrast, eligible defendants receive two important benefits: (I) an entitlement to treatment (likely at taxpayers' expense); and (2) protection from the risk of incarceration.
Put differently, the initiatives open wide disparities in the sentencing exposure faced by the eligible and the ineligible. Can these disparities be justified? This question requires a closer examination of the precise boundaries of eligibility. In essence, the initiatives exclude three classes of defendants: (I) those who possess with an intent to distribute, not just use; (2) those who have a nontrivial criminal history; and (3) those who are charged concurrently with an offense other than possession. In short, the initiatives seem designed to preserve incarceration as a possible sentence for everyone but the safest of safe bets, whom we might think of as the pure possession defendant. This policy, while perhaps unobjectionable in and of itself, raises various concerns when put into context.

First, the exclusions may discriminate against the poor and minorities. Substance abusers of limited means are apt to rely on ancillary forms of criminality in order to support their drug habits. They may become street-level sellers, or burglars, or otherwise render themselves ineligible for mandatory treatment, whereas the middle-class substance abuser may have the luxury of remaining a pure possession defendant. Likewise, minority defendants may face systematic exclusion as a result of law enforcement practices, such as racial profiling, that increase their likelihood of having a disqualifying criminal history. ${ }^{66}$

Second, granting that some defendants with disqualifying characteristics should be incarcerated as a matter of public safety, it is not clear why these, or any other ineligible defendants, should necessarily be denied the sort of entitlement to publicly financed treatment that is given to the eligibles. They may, in fact, be equally amenable to treatment. Moreover, because their substance abuse may be linked to other forms of criminality, society may actually benefit more by rehabilitating the ineligibles than the eligibles.

Third, if the sentencing disparity here is difficult to justify from the standpoint of rehabilitative purposes, it may be equally problematic with reference to other traditional purposes of sentencing, such as retribution and deterrence. It is not difficult to imagine troubling scenarios. For instance, consider a bust that nets two defendants: a middle-class buyer who uses drugs casually on weekends, and an addicted seller who distributes small quantities at the street level only in order to support his own habit. The buyer might qualify for treatment in lieu of incarceration, while the seller would not (and might in fact face a long mandatory minimum sentence). Yet, can we confidently say that the buyer is any less culpable, or that a period of incarceration for him would have any less deterrent effect? Indeed, a plausible case may be made that the buyer is the one who ought to be incarcerated, and the seller treated.

All of these concerns assume that, at sentencing, the judge will, in fact, treat the ineligible defendants 
differently. In many cases, of course, the judge will exercise discretion at sentencing so as to minimize unwarranted disparities. However, they cannot be counted on to do so on a systematic basis. First, the initiatives (other than Michigan's) leave mandatory minimums intact. Second, the initiatives may be understood to validate wide disparities between the eligibles and ineligibles: by negative implication, when the voters chose to protect only a particular class of defendants, they must have intended harsher treatment of the rest. Third, some judges who sentenced drug defendants harshly before the initiatives may be reluctant-as a result of inertia, ideology, or political sensibilities - to change their past practices as to ineligible defendants. Finally, the eligible defendants will presumably be first in line for scarce treatment resources. Thus, even judges who would be inclined to order treatment for some of the ineligibles might be unable to do so.

The concerns here parallel those articulated by Zimring, Hawkins, and Kamin. In one sense, the initiative drafters have overcome the electorate's tendency to vote so as to express hostility to criminals: the initiatives benefit only those drug defendants who are seemingly the most sympathetic, and their offenses have been recast from criminal in nature to medical. But, by excluding less sympathetic defendants, such as dealers and recidivists, the initiatives still allow voters to make a symbolic statement against those who are perceived to be the real criminals. Indeed, in the Arizona and Michigan Initiatives, the implicit condemnation of criminals becomes quite explicit: Proposition 200 denies parole to certain violent criminals, while the Michigan Initiative imposes a twenty-year mandatory minimum on certain dealers. Similarly, the Arizona, California, and Ohio initiatives all include within their stated purposes the objective of "preserving jails and prison cells for serious and violent offenders." ${ }^{67}$ In the end, the initiatives may do as much to validate as to call into question the account of punishment and democracy that is offered by Zimring and his colleagues.

When voters make sentencing decisions, crude distinctions between classes of defendants may inevitably follow. The Michigan Initiative, though, offers an intriguing alternative: delegation of discretionary authority to judges and expert sentencing commissioners. While the Initiative, on its face, provides for the same sort of disparate handling of eligibles and ineligibles as the other ballot propositions, it also empowers judges and commissioners to smooth some of the rough edges: it eliminates preexisting mandatory minimums, mandates systematic guidelines for drug sentencing, and offers judges the opportunity to admit some categories of defendants who would otherwise be excluded. The Michigan approach holds much promise-although its political viability has yet to be demonstrated. ${ }^{68}$

\section{Conclusion}

On their surface, the drug initiatives seem a quite different political phenomenon than the three-strikes initiatives. Yet, these two sets of initiatives may have more in common than meets the eye, including a mistrust of judicial discretion and a symbolic condemnation of crime and criminals. The Michigan Initiative, however, may presage a more significant departure from the typical dynamics of direct democracy and sentencing.

The four drug initiatives, while similar in spirit, differ significantly in structure. Assuming the initiative movement spreads to other states, even more variations will likely appear. No doubt, the initiatives will continue to reflect political sensibilities that vary from state to state and over time. We may also hope that the initiatives reflect the lessons learned from increasingly sophisticated analyses of the Arizona and California experiences.

\section{Notes}

Punishment and Democracy: Three Strikes and You're Out in California 203 (2001).

ld. at 192-93.

ld. at 200.

ld. at 201.

Proposition 200, § 10.

Id.

Proposition 200, §§ 6-7.

Proposition 200, $\S 5$.

Proposition 200, § 11.

Proposition 36, § 5(a).

Proposition 36, § 4(a).

Proposition 36, § 5(b)(1).

Proposition 36, § 5(b)(2)-(4).

Proposition 36, §5(c).

Proposition 36, §5(e).

16 Proposition 36, § 5(e)(3)(A).

Proposition 36, § 5(e)(3)(B)-(C).

18 Proposition 36, § 6(a).

19 Ohio Drug Treatment Initiative (visited June 18, 2002) <http://www.ohiodrugreform.org/fulltext.tp> reprinted infra 14 Fed. Sent. Rep. 350 [hereinafter Ohio Initiative]. The Initiative would add a new Section 24 to Article IV of the Ohio Constitution. Citations herein to specific provisions of the initiative will be made to subsections of the proposed Section 24.

${ }_{20}$ ld. $\S \mathrm{B}(1)$. Defendants will presumably request treatment as a matter of course, however, which may render this difference more a matter of form than substance.

${ }_{21} \quad l d . \S \mathrm{B}(2)$.

22 Id. $\S \mathrm{C}(1)(\mathrm{d})(\mathrm{iv})$.

${ }^{23}$ In some cases, the same result might be reached under a provision of Proposition 36 that excludes defendants convicted of "a misdemeanor not related to the use of drugs or any felony." Proposition 36, §5(b)(2). The intoxicated motorist would apparently be excluded in California if charged with a felony DUI or if intoxicated by alcohol and alcohol is not deemed to be a "drug." The motorist would not appear subject to exclusion in Arizona.

24 Ohio Initiative, supra note $19, \S \mathrm{C}(2)$.

${ }_{25}$ Id. $\S \mathrm{C}(3)$. This provision is subject to additional requirements and limitations. For instance, concurrent DUI charges are not covered. 
26 Id. $\S \mathrm{G}(2)-(3)$.

27 ld. $\S \mathrm{G}(1)$.

28 Id. $\S \mathrm{H}(3)$

ld. $\S \mathrm{I}(4)$.

ld. $\S I(5)$.

${ }^{31}$ A Petition to Reform Drug Sentencing Practices and Provide Treatment Instead of Jail Time for Certain Offenders in the State of Michigan (visited June 18, 2002) <http://

www.drugreform.org/Michigan/fulltext.tp> reprinted infra 14

Fed. Sent. Rep. 344 [hereinafter Michigan Initiative]. The Initiative would add new Sections 24 and 25 to Article I of the Michigan Constitution. Citations herein to specific provisions of the Initiative will be made to sections of the revised Article I.

32 Id. § 24

33 ld.

${ }^{34}$ Nine members must be drug treatment or health care professionals. A tenth must be a recovering addict. An eleventh must be an advocate for alternatives to incarcera. tion. A twelfth must be a public defender or defense attorney. A thirteenth (potentially enough to comprise a majority) must be a person who provides re-entry services to parolees. Id. While these 13 may, in fact, possess widely divergent views, one would expect a general predisposition towards treatment, which might be shared by any number of other members, who are to include politicians, judges, and members of the general public.

35 ld. $\S 25$.

36 ld.

37 Id.

$38 \quad l d$.

39 Id.

$40 \quad l d . \S 24$

41 Specifically, the cutoff amount is $\$ 500,000$, or $\$ 250,000$ if certain aggravating circumstances are present. $I d$.

$42 \quad$ ld. $\S 25$.

43 See United States v. Oakland Cannabis Buyers' Cooperative, 523 U.S. 483 (2001) (considering effect of federal antidrug law on medical marijuana cooperative operating pursuant to state law).

44 See Conference: Rethinking Our Drug Policy, 28 Fordham URB. L.J. 9, 86-87 (2000).

45 Arizona Administrative Office of the Courts Adult Probation Services Division, Drug Treatment and Education Fund Annual Report, Fiscal Year 1999, at 15 (2001) reprinted infra 14 Fed. Sent. Rep. 359 [hereinafter Arizona Report]. The early paraphernalia ruling was later reversed by the Arizona Supreme Court in State v. Estrada, 34 P.3d 356, 361 (Ariz. 2001).

46 Arizona Report, supra note 45 , at 13.

47 Id. at 19.

8 ld.

49 ld. at 7.

50 It is, to be sure, quite difficult to quantify the incapacitation benefits of imprisoning drug offenders. However, a recent study of recidivism by the Department of Justice contains some suggestive statistics. The researchers found that, among nearly 90,000 drug offenders released from state prisons in 1994, 66.7\% were rearrested within three years. Patrick A. Langan \& David J. Levin, Recidivism of Prisoners Released in 1994, at 8 (2002). Within this group, possession defendants actually had slightly higher rearrest rates than trafficking defendants (67.5\% to $64.2 \%)$. Id. Among the rearrested drug offenders, nearly $60 \%$ were rearrested for non-drug crimes, including nearly $20 \%$ rearrested for crimes of violence. (The researchers did not disaggregate this data for drug possession and drug trafficking convicts.) Assuming that some sizeable minority of drug offenders in the community will commit other types of crime, society gains a benefit by removing them from the community. The scope of those benefits, however, particularly in comparison with the marginal costs of incarceration, remains uncertain.

51 Drug Policy Alliance, Proposition 36 One-Year Progress Report (visited July 22, 2002) <http://www.prop36.org/ one_year_report.htm>. The Drug Policy Alliance is an advocacy organization that supports Proposition 36.

52 ld.

${ }_{53}$ See, e.g., Jeffrey S. Tauber, Rational Drug Policy Reform: A Resource Guide 4, 33 (2001). This resource guide is available on-line at <http:// www.problemsolvingcourts.com>.

54 See, e.g., Alan Johnson, Taft Calls Proposal for Drug Treatment a "Revolving Door," Columbus Dispatch, April 24, 2002.

55 Tauber, supra note 53 , at 8.

56 Ohio Campaign for New Drug Policies, Frequently Asked Questions 4 (visited July 25, 2002) <http:// www.ohiodrugreform.org/faq $>$.

${ }_{57} \quad l d$. at 5 .

${ }_{58}$ See John Wisely, Drug Reform Shifts Focus to Treatment, Not Jail, The Oakland Press, May 12, 2002 (quoting spokesman for Campaign for New Drug Policies criticizing drug courts on ground that judges "get to choose who qualifies .... That's a lot of power to give them.").

59 Proponents may share some of the concerns of Judge Morris B. Hoffman, who argues that, in drug courts, judges are sending more defendants to prison than in regular courts and for the wrong reasons. Morris B. Hoffman, The Rehabilitative Ideal and the Drug Court Reality, 14 FED. Sent. ReP. 172, 174-75 (2002) ("Drug court judges sentence defendants to prison not because the defendants used drugs but rather because the defendants refused to respond to our treatment efforts. This ... has nothing to do with justice, or with the disease model of addiction ....").

60 ZIMrIng ET AL., supra note 1, at 174.

${ }_{61}$ See William J. Stuntz, The Pathological Politics of Criminal Law, 100 Mich. L. Rev. 505, 546-57 (2001).

62 ld. at 552 .

63 Id. at 531, 550-51.

64 Vincent Schiraldi \& Judith Greene, Reducing Correctional Costs in an Era of Tightening Budgets and Shifting Public Opinion, 14 Fed. Sent. Rep. 332, 334 (2002). The scaling back of mandatory minimums is a trend that will be further detailed in the next issue of this journal, which will be devoted to recent developments in state sentencing.

65 William G. Meyer \& A. William Ritter, Drug Courts Work, 14 Fed. Sent. Rep. 179, 179-80 (2002). Whether drug courts reduce recidivism after the completion of treatment programs, however, remains more uncertain. Hoffman, supra note 59, at 173. Moreover, the benefits of drug courts may be outweighed by various costs, such as net-widening. See id. at $174-75$.

${ }_{66}$ Cf. United States v. Leviner, 31 F.Supp.2d 23, 33-34 (D. Mass. 1998) (departing downward from guidelines sentencing range based in part on conclusion that defendant's criminal history score "mirrors disparities in state sentencing, and in particular, racial disparities").

67 Proposition 36, § 3(c). Similar language may be found in Proposition 200, § 3, and Ohio Initiative, supra note 19, $\S A(4)$.

68 While sentencing guidelines have been quite controversial at the federal level, the state experience with guidelines has been somewhat happier, at least in some jurisdictions. Schiraldi \& Greene, supra note 64, at 3. Indeed, in my own state of Wisconsin, the legislature adopted new sentencing guidelines just this year. 